Reserch Atide

DOI: 10.24327/IJRSR

\title{
ASSESSMENT OF BIOFUEL POTENTIAL IN INDIA
}

Neha Sharma

\author{
University of Delhi, India
}

DOI: http://dx.doi.org/10.24327/ijrsr.2017.0805.0287

\begin{tabular}{l}
\hline ARTICLE INFO \\
\hline Article History: \\
Received $18^{\text {th }}$ February, 2017 \\
Received in revised form $10^{\text {th }}$ \\
March, 2017 \\
Accepted $06^{\text {th }}$ April, 2017 \\
Published online $28^{\text {th }}$ May, 2017 \\
\hline
\end{tabular}

\begin{abstract}
There is requirement to explore alternate energy sources to meet growing energy requirement of the present generation. Considering the fact that non-renewable resources are limited, fast-depleting and major contributor to harmful gases; biofuels are comparatively clean energy option available today. The present paper highlights the importance of biofuel production and relevance of important biofuel plants in India. The paper also discusses National Biofuel Policy framed by Indian Government in 2009.
\end{abstract}

\section{Key Words:}

Biofuel, energy

Copyright (C) Neha Sharma, 2017, this is an open-access article distributed under the terms of the Creative Commons Attribution License, which permits unrestricted use, distribution and reproduction in any medium, provided the original work is properly cited.

\section{INTRODUCTION}

With increasing human population, there is growing demand for energy consumption. Considering the current scenario of the world, fossil fuel is being a primary source of energy with its contribution of around $80 \%$ in meeting energy demand (Escobar et al., 2009). It is important to understand that these fossil fuel resources are limited on the planet. Moreover, there are several disadvantages of being dependent on fossil reserves. Firstly, the sources of these fossil fuels and oil reserves are depleting very fast. Secondly, they are responsible for emission of harmful gases which can pose several negative consequences like, receding of glaciers, loss of biodiversity, climate change, rise in sea level, etc. Thirdly, increasing demand for fossil fuel is also affecting the global economic activities as there is unprecedented rise in the prices of crude oil. It is therefore crucial to analyse scope of other alternative energy sources to meet energy requirement.

Biofuel crop are important source to derive energy. Researchers are continuously putting their efforts for the biofuel production from the sustainable biomass since it is being an efficient alternative against non-renewable fuels (Weldemichael et al., 2016). In comparison to non-renwable fossil fuels, biofuels have several significant advantages. Firstly, extraction process of biofuel from biomass is convenient and cost-effective. Secondly, biodegradable property of biofuel makes them a sustainable option. Thirdly, use of biofuel is more environment friendly. These important advantages of biofuel crop will result in surge of their dependency in automobile market during the next decade. Moreover, it is likely that biofuel production may result in growth of agricultural sector (Kim et al., 2005; Demirbas et al., 2008). Biofuels which are produced from biomass are referred to solid, liquid and gaseous fuels. Biofuel crop are divided into three generations as first, second and third depending on the chemical and complex nature of the biomass. The first generation fuels include biofuel which has been produced from the crop plants. Second generation consists of bioethanol and biohydrogen which is produced from agricultural by-products and energy plants which requires fertile lands for growth. Third generation biofuel include seaweeds and cyanobacteria which can be used for the production of biogas, bioethanol and biobutanol. Third generation biofuel crop produce large biomass in a stipulated time period and it doesn't require land for growth (Demirbas et al., 2008; Kang et al., 2014).

According to estimates of World Energy Outlook (WEO), the biofuel production across world has increased from approximately $20 \mathrm{Mt}$ in 2005 to $358 \mathrm{Mt}$ in 2007 (IEA, 2006). The transportation fuel demand is increasing in India thereby increasing the import expenditures. To reduce its reliance on imports, country through its policy regimes, now intends to promote eco-friendly options of biofuels. The ethanol production in India has increased from 0.15 Mt in 2005 to 2.5 Mt in 2007. Government of India in its policies has mandated $10 \%$ blending of ethanol with petrol which amounted to about 1100 million liters of ethanol use. Further, India aims to 
substitute $20 \%$ of diesel consumption by biodiesel production by 2017 (Ministry of New and Renewable Energy, 2009).

The new initiatives indicate the Government is keen in motivating production of biofuel within the country through its new policy measures and full R\&D support commitments. The biofuel production in India can be processed through the usage of molasses (for ethanol production), while for biodiesel production the best options are oilseed which are non-edible like Jatropha and Pongamia (Ministry of New and Renewable Energy, 2009).

\section{National Biofuel Policy}

India's national Biofuel policy was announced on 24th December, 2009 (Ministry of New and Renewable Energy, 2009). A national policy on biofuel is crucial in the growth and expansion of energy sector and its market in a country. Such policies can considerably govern the cost-effectiveness and availability of fuel alternatives or fuel blends in a country. This in turns can affect several sectors including agriculture, transport, industry, research and trade. National Policy of India was drafted so as to encourage use of renewable energy resources and encourage usage of alternate fuel as supplement with the conventionally used transport fuels. Further, the government has planned to switch $20 \%$ of its petroleum fuel consumption with biofuels (bioethanol and biodiesel) by the 2017. In order to achieve this target, the government has strongly implemented the Ethanol Blending Program (EBP). This program recommends $5 \%$ ethanol blending to be made obligatory in gasolin. Another important crucial point of this policy is that it plans to derive biofuel from non-feed stock that would be grown on degraded soils or wastelands, not otherwise suited to agriculture. An indicative 20-percent target for blending of biofuel for both biodiesel and bioethanol is proposed by end of 12th Five-Year Plan. It also envisages having Minimum Support Price (MSP) mechanism for inedible oilseeds to provide fair price to oilseed growers, subject to periodic revision. Oil Marketing Companies propose to purchase bioethanol at Minimum Purchase Price (MPP) based on the actual cost of production and import price of bioethanol. Government of India also plan to create a National Biofuel Fund for providing financial incentives, including subsidies and grants, for new and second generation feed stocks, advanced technologies and conversion processes, and production units based on new and second generation feedstock. National Policy also aims to meet the energy needs of India's vast rural population by stimulating rural development and creating employment opportunities. It also addresses global concerns about reduction of carbon emissions through use of environment friendly biofuels. To ensure their unrestricted interstate and intrastate movement of biofuels, Indian Government has declared biofuel to be under the ambit of "Declared Goods". Further, Biofuel technologies and projects would be allowed 100 percent foreign equity through automatic approval so as to attract foreign direct investment (FDI), provided the biofuel is for domestic use only, and not for export. This policy also include establishment of National Biofuel Steering Committee (NBSC) under Prime Minister to provide policy guidelines. Progress of the policy will be monitored by National Biofuel Coordination Committee (NBCC), which was suggested to be chaired by the Prime Minister. This policy also suggests that all the state governments should work closely, particularly the forestry department, research institutions, universities etc. for promotion and development of biofuel program in their respective states.

\section{Biofuel Crops in India}

India has vast potential to explore production of fuel from plants. Following are important crops which can be grown in India for biofuel production.

\section{Jatropha}

Jatrophacurcas (Linnaeus) belongs to the family of Euphorbiaceae and has considerable potential as biofuel crop (Openshaw, 2000). The plant also holds application to prevent and/or control erosion, to reclaim land, to act as a live fence, especially to contain or exclude farm animals and to be planted as a commercial crop. Jatropha is originally native of tropical America, but now is widely common in many parts of the tropics and sub-tropics in Africa/Asia. Another important advantage with this crop is that it is easy to establish, grows relatively quickly and is hardy and also drought tolerant. It is not browsed by animals as its leaves and stems are distasteful to animals. However, after treatment, the seeds or seed cake could be used as an animal feed. All parts of the plant are of medicinal value. Bark of Jatropha contains tannin which attracts bees and thus the plant has a honey production potential. Wood and fruit of this plant can be used for numerous purposes including fuel production. Its fruit contain viscous oil that can be used for soap making, in the cosmetics industry and as a diesel/kerosene substitute or extender. Its use as bio-diesel is important because it can be considered as practical substitutes for fossil fuels to counter greenhouse gas accumulation. However, the full potential of Jatropha has not been fully realized due to several reasons. Firstly, the growing and management of Jatropha is poorly documented. Secondly, there is less efforts put forward towards marketing its products. Therefore, actual or potential growers are generally reluctant to invest time and money in a crop that only has promise rather than concrete rewards.

Thus, it is timely to examine problems encountered in the growing and use of Jatropha, achievements to date and the present strategy in promoting this potentially useful and versatile plant.

\section{Pongamia}

Pongamiapinnata, is another important crop which can be used as potential biofuel crop. It belong to legume family and is nonedible, drought resistant tree, capable of adaptation to different climatic conditions. It is widely distributed in Asia, Australia and Pacific islands. Its seed oil represents a precursor for biodiesel production (Aniya et al, 2005; Dwivedi et al., 2014). The residual seed is suitable for bioethanol production because of the presence of holocellulose composition (Radhakumari et al., 2014). Several countries have initiated $P$. pinnata plantation programs as a source of renewable feedstock for the production of biodiesel. Such countries include Australia (Rural Industries Research and Development Corporation, Australian Government), India (National Oil Seeds and Vegetable Oils Development Board, the Ministry of Agriculture, India) and Hawaii (Source: Biodiesel crop implementation in Hawaii, Hawaii Agriculture Research 
Centre, 2006). As a result the annual yield of the seeds from India alone, reached 2,00,000 metric tons (Gaurav et al., 2011). The seeds consist of $30-35 \%$ oil which can be processed into biodiesel. The residue can be hydrolyzed to produce fermentable sugars for further biofuel production (Radhakumari et al., 2017).

\section{Camelina}

Camelinasativa or false flax belongs to the family Brassicaceae. The plant is widely grown as a feedstock for biodiesel in Europe and North America (Bonjean et al., 1999). It can be easily grown on marginal land as it has very less nutrients requirement (Ehrensing and Guy, 2008; Putnam et al., 1993; Singh et al., 2014). It has around $40 \%$ of oil content (Agarwal et al., 2010). For industrial uses, Camelina has application in cosmetics and bio-diesel fuels (Bernardo et al., 2003). Camelina has been studied for its biofuel potential and is considered to be better due to its lower life-cycle energy than traditional bio-diesel crops like soybean and canola (Krohn and Fripp, 2012).

\section{CONCLUSION}

Thus the present paper highlights importance of biofuel production considering growing energy requirement of world. India has developed National Biofuel Policy in 2009 which has targeted to develop biofuel production in coming years. Biofuel crops like Jatropha, Camelina and Pongamia are suitable to Indian climate. They hold potential to be further considered as sustainable fuel option in future. More research is required to assess impact biofuel crops on economics and society in India.

\section{References}

Agarwal, A., Pant, T. and Ahmed, Z., 2010. Camelina sativa: a new crop with biofuel potential introduced in India. Current Science, 99(9), 1194-1195.

Aniya, V.K., Muktham, R.K., Alka, K., Satyavathi, B. 2015. Modelling and simulation of batch kinetics of non-edible Karanja oil for biodiesel production: a mass transfer study. Fuel. 161, 137-145.

Bernardo, A., Howard-Hildige, R., O'Connell, A., Nichol, R., Ryan, J., Rice, B., Roche, E., Leahy. J.J. 2003.Camelina oil as a fuel for diesel transport engines. Industrial Crops and Products. 17, 191-197.

Bonjean, A., Goffic, F. 1999. La cameline: Camelina sativa (L.) Crantz: uneopportunité pour l'agricultureetl'industrieeuropéennes. OCL.Oléagineux, corps gras, lipides, 6(1), 28-34.

Demirbas, A. 2008. Biofuels sources, biofuel policy, biofuel economy and global biofuel projections. Energy Conversion and Management. 49, 2106-2116.
Dwivedi, G., Sharma, M.P. (2014) Prospects of biodiesel from Pongamia in India, Renewable and Sustainable Energy Review. 32, 114-122.

Ehrensing, D. T., Guy, S. O., 2008. Camelina, Oregon State University, Extension Service

Escobar, J.C., Lora, E.S., Venturini, O.J., Yanez, E.E., Castillo, E.F., Almazan, O. 2009. Biofuels: environment, technology and food security. Renewable and Sustainable Energy Review. 13, 1275-1287.

Gaurav, D., Siddarth, J., Mahendra, P.S. 2011. Pongamia as a source of biodiesel in India, Smart Grid Renewable Energy. 2, 184-189.

IEA, 2006.World Energy Outlook. International Energy Agency, Paris

Kang, Q., Appels, L., Tan, T., Dewil, R. 2014. Bioethanol from lignocellulosic biomass: current findings determine research priorities. Scientific World Journal.1-13.

Kim, S., Dale, B.E. 2005. Life cycle assessment of various cropping systems utilized for producing: bioethanol and biodiesel. Biomass- Bioenergy. 29, 426-39.

Krohn, B. J., Fripp, M. 2012. A life cycle assessment of biodiesel derived from the "niche filling" energy crop camelina in the USA. Applied energy, 92, 92-98.

Ministry of New and Renewable Energy, 2009. National Policy on Biofuels

Openshaw K. 2000. A review of Jatrophacurcas: an oil plant of unfulfilled promise. Biomass and Bioenergy. 19, 1-15.

Putnam, D. H., Budin, J. T., Field, L. A., Breene, W. M., 1993. Camelina: a promising low-input oilseed. In New Crops (edsJanick, J. and Simon, J. E.), Wiley, New York, pp. 314-322

Radhakumari, M., Ball, A.S., Bhargava, S.K., Satyavathi, B. 2014. Optimization of glucose formation in Karanja biomass hydrolysis using Taguchi robust method, Bioresour. Technol. 166, 534-540.

Radhakumari, M., Taha, M., Shahsavari, E., Bhargava, S. K., Satyavathi, B., Ball, A. S. 2017. Pongamiapinnata seed residue-A low cost inedible resource for on-site/in-house lignocellulases and sustainable ethanol production. Renewable Energy. 103, 682-687.

Singh, R., Nasim, M., Tiwari, S. 2014. Camelina sativa: success of a temperate biofuel crop as intercrop in tropical conditions of Mhow, Madhya Pradesh, India. Current Science. 107, 359-360.

Weldemichael, Y., Assefa, G. 2016. Assessing the energy production and GHG (greenhouse gas) emissions mitigation potential of biomass resources for Alberta. Journal of Cleaner Production. 112, 4257-4264.

\section{How to cite this article:}

Neha Sharma.2017, Assessment of Biofuel Potential in India. Int J Recent Sci Res. 8(5), pp. 17125-17127.

DOI: http://dx.doi.org/10.24327/ijrsr.2017.0805.0287 